\title{
傾斜平面ステレオによる走行可能路面と障害物の検出
}

\author{
木 村 茂*1 田野 浩 明*2 坂 本 卓 也*2 \\ 城 間 晴 輝*1 大 橋 洋 一*1
}

\section{Traversable Region and Obstacle Detection Using Tilted-plane-based Stereo Vision}

\author{
Shigeru Kimura*1, Hiroaki Tano*2, Takuya Sakamoto*2, \\ Haruki Shiroma*1 and Yoichi Ohashi*1
}

\begin{abstract}
For autonomous mobility of unmanned or tele-operated vehicles, the visual navigation capabilities such as obstacle detection and terrain estimation are essential. This paper presents a robust model-based approach for detecting traversable regions and obstacles even in off-road environments. In our approach, a model-based polynocular stereo, which we call tilted-plane-based stereo, is utilized. We newly define the algorithm by using a group of slant parallel planes to be searched in the spatial disparity space. It is capable of directly measuring height differences in the view field. By checking abrupt jumps in height in the 3D space, traversable regions of the terrain can be effectively estimated. Then, the obstacles belong to the untraversable regions are robustly detected. We show successful results of the proposed method for different obstacles in the real scenes.
\end{abstract}

Key Words: Stereo Vision, Model-based Stereo, Obstacle Detection, Vehicle Navigation

\section{1.はじめに}

本論文では, 野外不整地等の複雑な環境下においても適用で きる，ステレオ視による効率的な走行可能路面と障害物の検出 方法を提案する。提案する方法の最大の特徴は, 複雑な環境下 において適用するため, 車両の車輪で踏破できるかどうかの判 断基準である段差に着目している点にある．また，通常のステ レオ視ではカメラの光軸に垂直な平面を探索するが，ここでは 傾斜した平面を探索するステレオ法（以下，傾斜平面ステレオ 法と呼ぶ）を用いる。この傾斜平面ステレオ法により, 段差の 有無を直接計測する。段差の有無が分かれば, 走行可能領域や 障害物は比較的簡単な処理で検出できる.

自律的に移動するロボットまたは車両を実現するには，どこ が走行できる路面で, どこが障害物かという, 進行方向前方の環 境情報の取得が必要で，それも，どれだ高速にかつ正確に取得 できるかが重要な技術課題となる，確かに，工場やオフィス内の 屋内を移動するロボットは実用化されてきているが, 特定のデ モシステムを除くと, 屋外の複雑な環境下で人間と同じように 自律的に移動できるロボットはまだ技術的に難しい. 米国防総省 DARPA（Defense Advanced Research Projects Agency）の

原稿受付 2003 年 5 月 27 日

*1 防衛庁技術研究本部

*2 小松製作所特機事業本部

${ }^{* 1}$ Technical R\&D Institute of Japan Defense Agency

${ }^{* 2}$ Defense Systems Division, Komatsu Ltd.
UGV (Unmanned Grand Vehicle) プロジェクトである Demo III, 自律走行車が競う DARPA グランド・チャレンジの達成状 況などを見ても，一般の野外の環境での走行となると自律走行 はまだ末完成で，現在，かなりの部分は人間が介在して遠隔操 作せざるを得ない，自動化が難しい分野である，本論文は，この ような技術課題を克服するための研究の一つの成果であり, 野 外不整地等の複雑な野外環境での画像センサよる自律走行を目 的としたものである.

従来, 車両の自律走行を目的とした視覚センサの研究が数多 く行われている. 例えば, 白線など道路固有の特徵を抽出して 路面を検出する方法 [3]～[5], 車両の姿勢から路面に相当する平 面の式を求め,この平面上に左右のカメラ画像を投影したとき の差分から路面と非路面領域（障害物）を区別する方法 [6], 想 定する路面を平面の方程式や画像間の平面射影変換行列で扱い, この平面の方程式や平面射影変換行列で変換した画像とのマッ チングによって路面と非路面領域を判別する方法 [7]〜 [9], 道路 の特徽と想定路面を併用して処理を高速化する方法 [10] などが ある.しかしながら, 白線などの道路の特徵を抽出する方法は, 高速道路などの整備された理想的な走行環境を前提とした方法 である．当然，このような方法では，ここで想定する一般の野 外環境では使用できない。一方，平面的な路面を前提として何 らかの方程式や変換行列でモデル化し推定する方法は, そのモ デル化により処理範囲の限定ができるため一般の舗装道路など を対象とすればかなりのシーンで適用できる効率的な方法であ る.しかし，ここで想定するような一般の野外環境, 例えば野 
外不整地等の複雑な環境下で適用するには，対象が複雑となる ため単純な一つの平面モデルだけでは平面推定の安定性や検出 能力に限界がある. 提案する方法では, 傾斜平面ステレオ法に より, 車両に搭載されたカメラから見て走行可能な理想的な路 面（基準路面）を基準として, 進行方向に傾斜した複数の平面を 定義し, 進行方向前方の路面がそれらのどれに属すか探索する. 探索される平面は傾斜しているため, 基準路面からの相対的な 高さが異なる平面群となる，その選択された平面の変化（高さ の変化）から, 直接, 段差を検出する. 本方法は平面モデルを 使用しているが，前述の従来方法のような一つの平面モデルで 対象を記述しようとするものではない. 本方法では, 複数の平 面 (傾斜した平面群) により複雑な形状を記述し, 段差検出に 利用している. そのため, 野外不整地等の環境下での複雑な地 形や障害物に対しても頑健に動作する。

以下, 本論文では, 2 章で提案手法の概要を述べる， 3 章で は, 通常のステレオ処理と比較して, 傾斜平面ステレオ法の処 理はどこが異なり，どのような演算になるのか詳しく述べる. 4 章で段差に着目した走行可能路面の推定と障害物の検出の方法 について説明し，5章では野外環境での処理例を用いて本方法 が良好に適用できることを示し, 最後に 6 章では提案方法の有 効性がどこにあるかを示す。

\section{2. 提案方法の概要}

自律走行のようなリアルタイム性が必要な応用においては, いかに早い段階で, 必要な情報を含んだ，より少ないデー夕に 加工できるかが重要となる. 提案方法の最大の特長は, 傾斜平 面ステレオによりステレオ処理の出力の段階で, 簡単な処理で 路面や障害物を検出できるデー夕（高さに関連する情報である モデル值 $m$ ）を得ているところにある.

本方法での路面や障害物の検出は, まず確実に走行できる路 面を検出して, それ以外は障害物であると判断するやり方で行 う. 路面の検出は, 走行可能な路面であるか否かを車両の踏破 性で判断する。 また, その車両の踏破性は, 路面の段差が許容 できる段差に収まっているかどうかで評価する，そのため，力 メラから対象までの距離ではなく, 水平の基準位置（例えば理 想的な路面）からの高さが重要な評価值になる，例えば，各画 素の距離（または視差）から, 幾何的な計算により高さを算出 することもできるが, ここでは，3 章で詳述する傾斜平面ステ レオ法により, 直接的に高さの情報を抽出する. また, この傾 斜平面ステレオ法では, 単なる視差から高さへの計算処理を省 くだけでなく, 路面のような対象を的確に検出しやすくなると いう利点がある.

提案する方法の概略の処理の流れを Fig. 1 に示す. 提案する 方法は, (1) 傾斜平面ステレオの処理, (2) 走行可能路面の抽出, (3) 障害物の検出の各処理からなる.まず (1) の傾斜平面ステ レオにより，外界の状況をカメラから見た理想的な路面（基準 路面）からの相対的な高さとして算出する. 次に，(2)の走行 可能路面の抽出は, (2-1) 高さの変化から段差を検出し, (2-2) 進行方向前方について段差が検出されるまでの点を移動可能点 として抽出し, (2-3) それらの移動可能点群から走行可能な路面 を推定することにより行う. 最後に (3) の障害物の検出は, 推

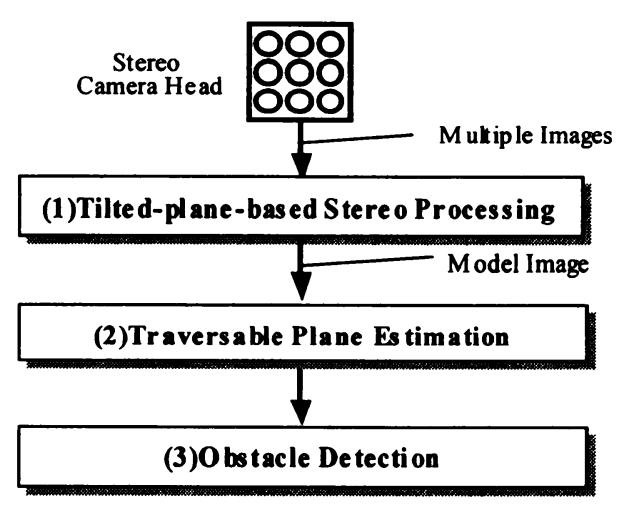

Fig. 1 Processing flow of our proposed method

定した走行可能な路面から外れた領域を障害物として検出する 処理である.

\section{3. 傾斜平面ステレオ法}

本章では, 通常のステレオ処理での視差探索, 次に傾斜を有 する路面モデル群を導入した傾斜平面ステレオの路面モデル探 索とではどこが異なり，どのような演算が行われるのか述べる.

\section{1 関連する研究}

傾斜平面ステレオの処理結果は, 米国 Sarnoff 社や CMU (Carnegie Mellon University) のWilliamson 等が使用した Tilted Horopter Stereo と呼ばれるモデルベースのステレオ処 理とほほ同じになる [11] [12]. しかし，処理の基本となる枠組 みが異なる. Sarnoff 社の場合は, 左右画面を対象に画面全体で マッチングする領域を路面と仮定している．画像全体のマッチ ングはアフィン変換係数として算出し, その係数で一度ワープ （アフィン変換）してから, 残りの視差を高さの情報として算出 する. 路面（平面）で生じる左右画面の視差を，正確な計算を 行う平面射影変換ではなくアフィン変換で簡略化して扱ってい る.一方, CMU の Williamson 等は, 対応点座標計算を含む キャリブレーション (幾何補正) の枠組みを利用し，その中で無 限遠点と理想路面の平面射影変換行列から三次元空間の傾斜平 面群を定義し，それを使用して探索処理を行っているため，全 体としての計算の見通しが良くない．以下に示すように，我々 の方法では，画像全体のマッチングを前提としていない.また， 幾何補正のためのキャリブリレーションとは切り離し，画像視 差空間で複数の傾斜平面を定義して，そのどの平面にあるか探 索するという，見通しの良い枠組みで整理している.

\section{2 従来のステレオ処理と視差の探索}

$F$ をカメラの焦点距離とすれば, 三次元空間中の点 $P=$ $(X, Y, Z)^{t}$ はカメラ座標上の点 $p=(x, y)^{t}=(F X / Z, F Y / Z)^{t}$ に写る. その三次元空間中の点 $P$ をカメラ間隔 $B$ のステレオ ペアで計測し, 視差 $d$ が生じたとすると, カメラからの距離 $Z$ は式（1）で算出される.

$$
Z=\frac{B F}{d}
$$

この視差 $d$ を求めること, すなわち, カメラ間の対応点探索 がステレオ視の処理となる。この対応点探索は, 例えば, 差の 二乗 SD（Squared Difference）や差の絶対值 AD（Absolute 
Difference）などの評価関数を用いて行う。次の式は， $(n+1)$ 個のカメラを有する多眼ステレオの場合のステレオペアの $\mathrm{AD}$ を積算した SAD（Sum of Absolute Differences）の評価式で ある。

$$
Q_{S A D}(x, y, d)=\sum_{r=1}^{n}\left|F_{r}(x, y, d)-I_{0}(x, y)\right|
$$

ここで使用している仮定視差 $d$ は, 基準となるステレオペア での視差值である。また, $I_{0}(x, y)$ はカメラ $C_{0}$ の画像の位置 $(x, y)$ の画素値, $F_{r}(x, y, d)$ は仮定視差 $d$ と仮定した場合のカ メラ $C_{r}$ の対応候補点の画素值である. なお，関数 $F_{r}(x, y, d)$ はカメラ配置等で決まるもので幾何補正関数（カメラが並行で 正確に格子状に配列され光軸が並行な場合は，上下に位置がシ フトする簡単な式になる。 また, 複雑な配置でも平面射影変換 行列等を用いて計算できる) である。このある 1 点の評価関数 では，対応の暧昧さを低減できないので，実際の対応点の探索 は，点の周りの状況も加味したウインドウ領域 $R$ で加算処理を 行った, 次の SSAD (Sum of SADs) の評価関数で行う.

$$
Q_{S S A D}(x, y, d)=\sum_{(p, q) \in \Re} Q_{S A D}(x+p, y+q, d)
$$

ステレオ視では, 画像の各点でこの SSAD の最小値を与える仮 定視差 $d^{*}$ を探索して, 視差を推定することになる.

$$
d^{*}(x, y)=\arg \min _{d}\left\{Q_{S S A D}(x, y, d)\right\}
$$

各座標で推定視差を保持した画像配列 $d^{*}(x, y)$ は視差画像, また視差を探索する $(x, y, d)$ の空間は画像視差空間（Spatial Disparity Space）（以下，簡単化して視差空間と表現）と呼ば れる [1]. 視差空間で視差 $d=$ 定数の平面は, 三次元空間では カメラの光軸に垂直な平面に対応する。一般に，三次元空間の 平面は視差空間で平面になり，逆に視差空間の平面も三次元空 間の平面になる，通常のステレオ視では，カメラの光軸に垂直 な平面群のどこにあるかを調べていることになる．視差探索に 使用する仮定視差は通常，画面上で等間隔に取るので，三次元 空間での対応する平面は手前では間隔が狭く（距離分解能が高 くなる), 遠くでは平面の間隔は広くなる（距離分解能が低く なる).

\section{3 傾斜平面ステレオ法による路面モデルの探索}

通常のステレオ視では三次元空間でカメラに垂直な平面を探 索するが，カメラから見て傾斜した平面を探索する方法でもス テレオ視を行うことができる．例えば，Fig. 3 に示すような， 車両に搭載し下方に $\theta$ だけ傾けた高さ $H$ のカメラを考える. このとき, Fig. 3 の点 $R$ を通る水平な理想的な路面（基準路面 と呼ぶ）の平面は, カメラを中心とした $X Y Z$ 座標系で,

$$
Z=\frac{Y \cos \theta+H}{\sin \theta}
$$

で表される。この基準路面のモデル番号を零として定義してお く. 基準路面をステレオ視の視差值 $M_{0}(y)$ で表すと,

$$
M_{0}(y)=\frac{B}{H}(F \sin \theta-y \cos \theta)
$$

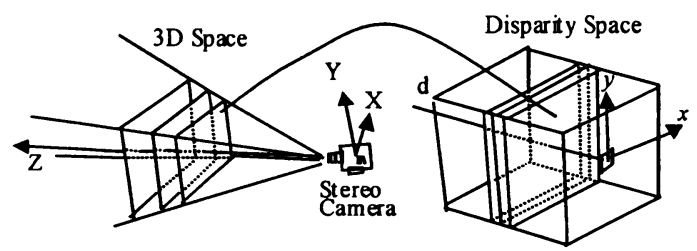

(a) Normal stereo matching

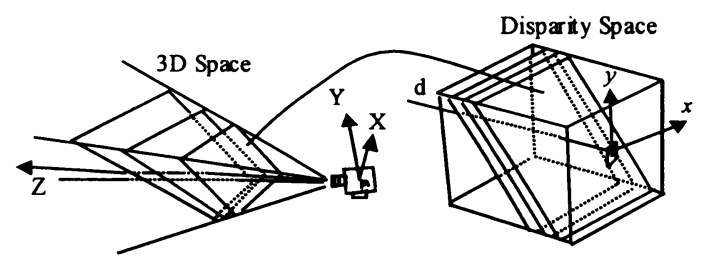

(b) Tilted-plane-based stereo matching

Fig. 2 Comparison of traditional stereo matching and tiltedplane-based stereo matching

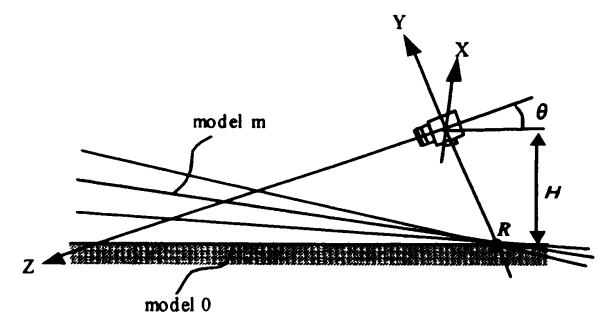

Fig. 3 Tilted road planes to be searched in our tilted-planebased stereo method

となる。これは視差空間で傾斜した平面になるが,この傾斜した 視差空間の平面に並行に並ぶ平面群を定義し，これらの平面群 のどの平面に属すか調べ，ステレオ視の処理を行う（Fig. 2 (b) 参照)。このとき, Fig. 3 に示すように, 三次元空間の対応する 路面モデルの平面は, 点 $R$ を共有し扇状に広がった平面群にな る。ここでは，視差（距離）を探索するというょり，設定した 平面のモデルのどれに当たるか探索するので，平面のモデル番 号（モデル值） $m$ を決定する処理になる．モデル值 $m$ が正だ と基準路面より上，負だと下に傾斜した平面となるように定義 する. モデル值 $m$ の絶対值が大きいほど大きく傾斜した平面 となる.

定数 $\alpha$ を視差空間での路面モデルを刻む視差の間隔とすれ ば, $y$ 座標にあるモデル值 $m$ の点の視差值は $M_{0}(y)+\alpha m$ で あり, 三次元空間でのその点の基準路面からの高さ $h(y, m)$ は 次式で与えられる（付録 A).

$$
h(y, m)=\frac{\alpha m H^{2}}{B(F \sin \theta-y \cos \theta)+\alpha m H}
$$

また，モデル值 $m$ の值により平面の勾配が変化するが，その 勾配 $s(m)$ は次式で計算される（付録 $\mathrm{B}$ ).

$$
s(m)=\frac{\alpha m H \cos \theta}{B F+\alpha m H \sin \theta}
$$

これらの路面モデルを使用してステレオ視を行う場合，視 差を推定する場合の式 $(2) \sim(4)$ に対応する評価式は， $d$ を $M_{0}(y)+\alpha m$ で置き換える形になり，それぞれ，式 $(9) \sim(11)$ 
になる，

$$
\begin{gathered}
Q_{S A D}(x, y, m)=\sum_{r=1}^{n}\left|F_{r}\left(x, y, M_{0}(y)+\alpha m\right)-I_{0}(x, y)\right| \\
Q_{S S A D}(x, y, m)=\sum_{(p, q) \in \Re} Q_{S A D}(x+p, y+q, m)
\end{gathered}
$$

$$
m^{*}(x, y)=\arg \min _{m}\left\{Q_{S S A D}(x, y, m)\right\}
$$

なお， $M_{0}(y)$ はカメラの取り付け位置や角度から式 (6) で計 算できるが, 実際には夕イヤ空気圧の変化など色々な要因で䛊 差が生じるので, 平坦な路面が写る通常のステレオ視の視差画 像から基準路面を推定して設定することもできる。

\section{4 傾斜平面ステレオ法の特徴}

傾斜平面ステレオでは, モデル值 $m$ に対応させて, 三次元空 間ではなく，視差空間で基準路面に平行な平面を探索するよう にしている. 仮に三次元空間で基準路面に平行に直接, 高さに 対応した複数の平面を設定し探索する方法を取ると, 画像の位 置によっては，平面を変えても画面上の変位が検出できないた め探索平面を区別できなくなるうえに，画像面上での探索が非 均一で探索の効率が悪くなる. あえて三次元空間で傾斜した平 面になるモデルを使用するのは，ステレオ視では画像解像度の 制約から撮像画面上での対応点の変位をほぼ等間隔にしか計測 できないためである。特に, ステレオ視では撮像画面上での探 索間隔の均一性が重要となる。傾斜平面ステレオでは, 視差空 間で平行に探索平面を設定しているため, 撮像画面上での探索 間隔は均一になる。

視差空間に対応させて，この傾斜平面ステレオで探索するモ デル值 $m$ と $x y$ 座標で構成される空間をモデル空間と呼ぶこ とにする。傾斜平面ステレオでは，通常のステレオと同じよう に, 各画素ではモデル值が得られる。 モデル值で構成された画 像をモデル画像と呼ぶことにする。このモデル画像は, カメラ から対象までの距離ではなく, 式（7）に示すように基準路面か らの高さの情報を表している. Fig. 4 は, 演習場の戦闘車両に 対して, 従来のステレオ処理による視差画像と, 傾斜平面ステ レオで得られたモデル画像の例を示したものである。このよう に, モデル画像では, 高さに応じた情報が直接的に得られるこ とが分かる. 傾斜平面ステレオで得られるモデル值は, 理想的 な状態では通常のステレオで得られる視差を座標計算により変 換して求めても同じ值を得ることができるが, 式 (10) の評価 值の集積範囲 (ローカルサポートの範囲) が異なるため, 対象 の形状に依存して抽出の安定性などの性質が異なる。対象が設 定した平面であると, SSAD の值が対象に適合する形でウイン ドウ領域全点でミニマムを取る可能性が高く, 平面を的確に抽 出しやすくなる.

Fig. 1 に示すように, 本論文の障害物の検出では, まず確実 に走行できる路面を優先して検出し, 次に, 検出された路面か ら外れるものは障害物であると判断する手順を取る。このため, 走行できる路面は確実に検出する必要がある. しかし, 逆に障 害物と思われる領域をいくら細かく調べても, 障害物であるこ

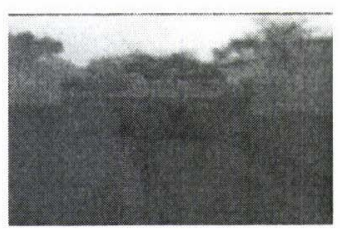

(a) Original image

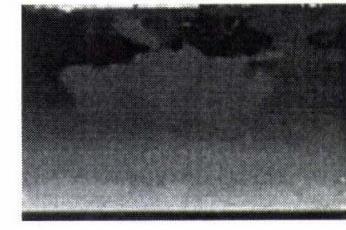

(b) Disparity image

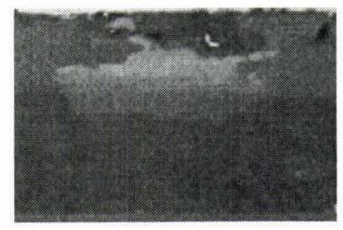

(c) Model image
Fig. 4 Disparity image by traditional stereo and model image by tilted-plane-based stereo

とに変わりはなく，車両の走行を制御するのには直接は役立た ない，車両自体の性能から走行できる路面が制限されるなら，そ の範囲に調べるモデルの数（探索範囲）を限定することが可能 で, 通常のステレオに比べて, 演算量を低減できるなどの特長 がある。

\section{4. 走行可能路面の推定と障害物の検出}

本章では, 走行可能路面がどこにあるか推定する方法, および その走行可能路面から外れた障害物の検出方法について述べる.

\section{1 段差に着目した走行可能路面の推定}

前章では，傾斜平面ステレオにより基準路面からの相対的な 高さの情報がモデル画像として得られることを示した．人工的 な環境下で路面が常に水平で, 路面に対してカメラの位置がず れなければ，得られるモデル画像に対して単純なしきい值処理 で簡単に障害物を検出できる。しかし，野外で自走するような 車两に搭載したカメラで撮像する場合, 車体の動摇等によるカ メラ位置の変動を考慮しなければならない，また，凹凸の障害物 を含む複雑な路面や傾斜した路面の場合がある．Fig. 5 は，野 外で撮影した画像に対してモデル画像を計算した例である。こ の場合の実際の走行可能な路面は, 理想的な基準路面（モデル 值零) から，大きく下側にずれている。この例のように，野外 では, 車両に搭載したカメラの動摇により, 路面のモデル值が ずれて出てくるため単純なしきい值处理では小さな障害物を検 出するのは難しい，そのため，まず段差に着目して走行可能路 面が実際にどこにあるか検出する。

Fig. 6 は，そのやり方を図示したものである.まず，移動可 能点を抽出する列の手前（画像の下端）から順次前方（画像の 上端）に向けてモデル画像を調べ，そのモデル值（高さ）の変 化から段差があるかどうか判断する，段差の有無は，調べる画 素の上下のある範囲のモデル值の平均值の差の大きさを計算し て決定する。そして，手前から段差があるまでの点を移動可能 点として何点か抽出する．5 章の実験例では, 計算量を削減す るため，全画面の全点を調べるのではなく，画面の下側を中心 に予め決めた $12(\mathrm{H}) \times 5(\mathrm{~V})$ の 60 点の格子状の候補点位置で, 移動可能点かどうか選択している。得られた移動可能点群から 走行可能な路面（平面）は, 最小自乗法で推定することができ 


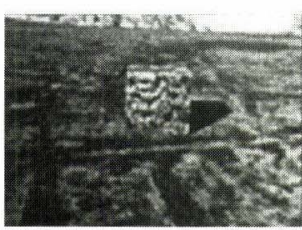

(a) Input image

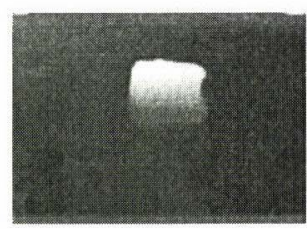

(b) Model image

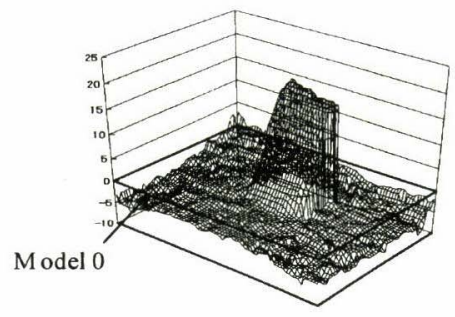

(c) 3D view of the model image

Fig. 5 Example of a model image under the practical environment

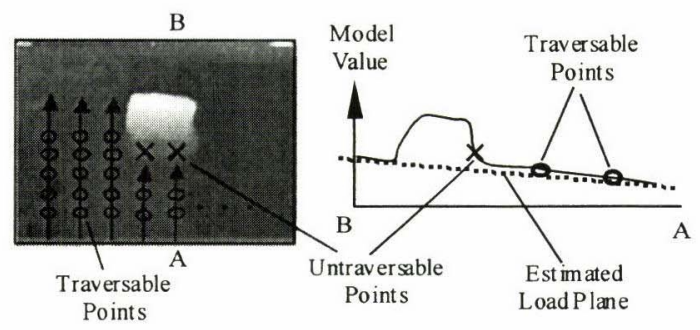

Fig. 6 Extraction of traversable points and estimation of actual road surface

る（ここでは，路面は単純な平面の路面としているが，なだら かに傾斜が変化するような路面は二次曲面等でモデル化するこ ともできる)。なお，推定した走行可能な平面はモデル空間で の平面であるが，このモデル空間の平面も三次元空間で平面に なる。

\section{2 障害物領域の検出}

モデル画像から走行可能な路面が決定されたなら, それから 外れる領域が障害物領域となる。よって，モデル画像上で走行 可能路面のモデル值と差を取り，しきい值を超えるか調べ，超 えている部分を障害物として検出する。しかしながら, 単純な しきい值処理では, 障害物を切り出すことは難しい。通常, ス テレオカメラは固定された視野角で，ある距離範网の計測しか カバーしていないため, 固定しきい值では遠近の広い範囲の障 害物を一様に抽出することはできないからである。例えば，画 面の中央部で障害物を検出するしきい值を，そのまま画面の下 部に適用すると, 近くにある踏破可能な小さい起伏も障害物と して検出してしまう。そこで，ここでは，カメラから遠くでは モデル值を基準としたしきい值処理，近くでは高さを基準とし たしきい值処理を行う複合型のしきい值処理を行う。これによ り, 遠近を含む画面全体で, 障害物の切り出しを適切に行える.

モデル值 $m$ と高さの関係式 (7) から, カメラ座標が $y$ 座標 である点が三次元空間で基準路面から高さ $h$ にある場合，その 点のモデル值 $m(y, h)$ は次式で計算できる.

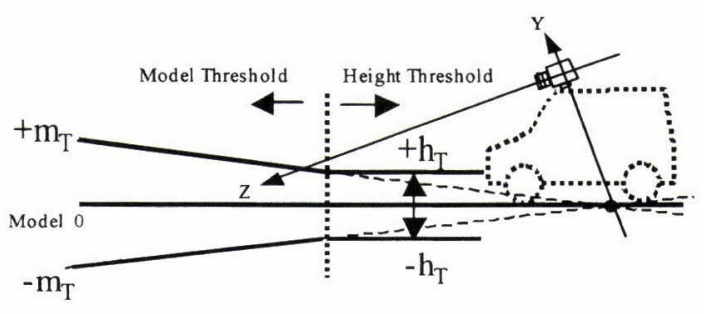

Fig. 7 Combined threshold based on height and model value

$$
m(y, h)=\frac{h B(F \sin \theta-y \cos \theta)}{\alpha H(H-h)}
$$

このモデル值を用いて，高さを基準としたしきい值処理を以 下のように行う。まず，高さのしきい值 $h_{T}$ を設定する。これ は車両の車輪の大きさ，乗り超えたときの衝撃の大きさなどを 勘案して決め, この值以上の高さのものを障害物として検出す るためのしきい值である。この高さのしきい值 $h_{T}$ を用いて, 画面下から上方に向かって高さ $h=h_{T}$ としたときの式 (12) で定まるモデル值（ $y$ 座標により変化）をしきい值として，モ デル值の差を評価する (高さしきい值の領域). 高さによるしき い值（モデル值）が, ある指定值（モデルのしきい值 $m_{T}$ で固 定）を超えたところから上方は，モデル差の固定しきい值で障 害物を検出する (モデルしきい值の領域). Fig. 7 は, モデル 值で評価するかまたは高さで評価するか, 車両からの距離によ り切り替わる複合型のしきい值処理のやり方を図示したもので ある。ここでは, 図が複雑となるので, 便宜上, 走行可能路面 を基準モデル (モデル值零) として示している.

\section{5. 実 験 例}

\section{1 多眼ステレオシステム}

実験に使用した多眼ステレオシステムは，筆者らが以前に開 発したシステム $[2]$ と基本的な処理の流れは同じである。ただ L, 基本演算の動作周波数は $40[\mathrm{MHz}]$ で処理性能は約 2 倍で, レンズ歪みの補正やオクルージョン処理等の機能強化した 9 眼 の実時間ステレオシステムとなっている. 多眼ステレオシステ ムの仕様は Table 1 の通りである。この多眼ステレオシステ ムでは, 動作モードを通常の距離（視差）モードまたはモデル モード（傾斜平面ステレオ処理を行うモード）にレジスタ設定 で瞬時に切り替えられるようになっている。また, モデルモー ドとしての基準路面の視差值 $M_{0}(y)$ を格納する 1 画面分のバッ ファをハードウェアの一部として持っている. 実験では，カメラ の取り付けのズレや乗員の乗り降りによる影響を取り除くため, 実際の理想的な路面のデータを計測して，このバッファを設定 している，それには, 一度, 距離モードで, 基準路面となる理想 的な路面を含む画像を撮像して通常のステレオ視の視差画像を 計測する。そして，その視差画像から余分な領域を手動で排除 し基準路面を平面推定（平面のパラメー夕を推定）する. 推定 した平面のパラメータから, 理想的な視差画像を生成し $M_{0}(y)$ のバッファに書き込む. その後, モデルモードに切り替えるこ とにより，傾斜平面ステレオとして動作させることができる．

画像を撮像するカメラは $1 / 3$ インチの白黒カメラでレンズの 焦点距離 $F=6[\mathrm{~mm}]$, 視野角は水平 $22.5^{\circ}$, 垂直 $17.5^{\circ}$ であ 
る. Fig. 8 に，多眼ステレオシステムと計算機類を搭載する車 両プラットフォームの外観を示す。この車両は普通乗用車（スズ

Table 1 Specification of our polynocular stereo machine

\begin{tabular}{l|l}
\hline Num. of Cameras & \multicolumn{1}{|c}{9} \\
\hline Input Image Size & $320(\mathrm{H}) \times 240(\mathrm{~V}) \times 8$ bits \\
\hline Processing Speed & $40 \mathrm{MDPS}($ Million Depth-pixel Per Second) \\
\hline Operation Mode & Depth or Model Mode \\
\hline Frame Rate & 30 Frames/Sec $(300 \times 220$ with 20dp) \\
\hline Other Functions & $\begin{array}{l}\text { Geometric Calibration, LoG Filter } \\
\text { Subpixel Disparity, Pyramidal Outputs }\end{array}$ \\
\hline
\end{tabular}

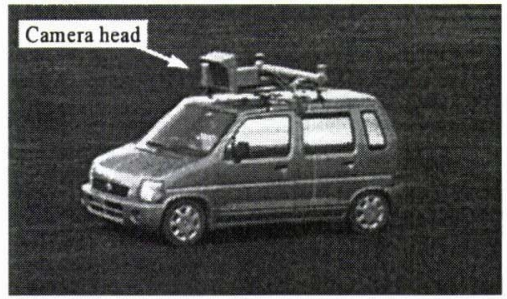

Fig. 8 Vehicle with a nine-eye stereo camera head
キ (株) 製 WAGON-R WIDE) を改造したものであり，多眼 カメラへッドは車両の上部に取り付けられている。 カメラへッ ド車載時の路面から基準カメラまでの高さ $H$ は $1.81[\mathrm{~m}]$, カメ ラのチルト角 $\theta$ は水平面に対し下向き $15^{\circ}$ である. 多眼カメラ のカメラ 9 台は水平 $15[\mathrm{~cm}]$, 垂直 $10[\mathrm{~cm}]$ の間隔で $3 \times 3$ の格 子状に配置されている．以下の実験では，傾斜平面ステレオの とき,マッチングに使用する画像データは LoG (Laplacian of Gaussian) フィルタ処理後の画像データ (4 bits), マッチング のウインドウサイズは $15 \times 15$ ，モデル平面の刻み幅 $\alpha=0.25$, モデル探索範囲は \pm 20 モデルと設定して動作させている。ま た，障害物検出のしきい值は，モデルしきい值 $m_{T}=4.0$, 高 さしきい值 $h_{T}=0.3[\mathrm{~m}]$ とした。この多眼ステレオで得られ るモデル画像から，走行可能路面や障害物等の情報を計算する ための処理装置として，計算機（Pentium III $1 \mathrm{GHz}$ 相当）を 数台（車両の移動経路選択, 車速やステアリングを制御する操 舵ベクトルの生成等の機能を実行）を付加している.

\section{2 野外シーンに対する処理例}

ここでは, 野外シーンに対して, 提案する傾斜平面ステレオ

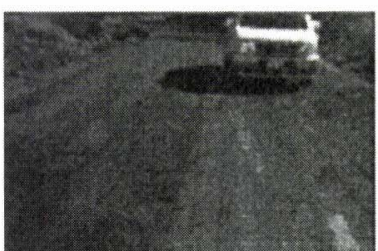

Original image
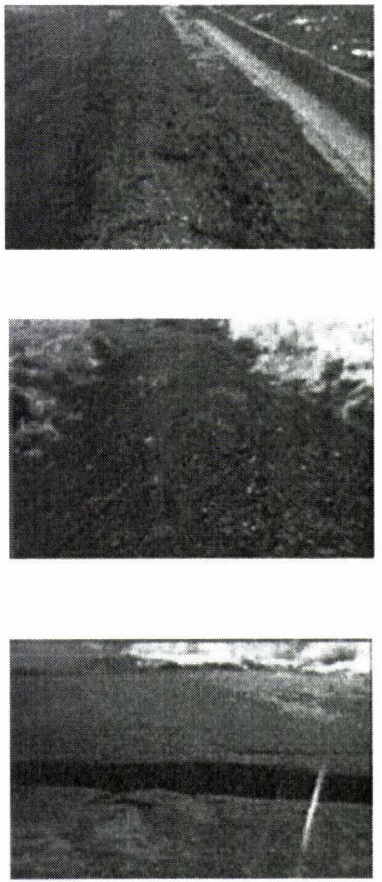

Detected obstacles(white regions)

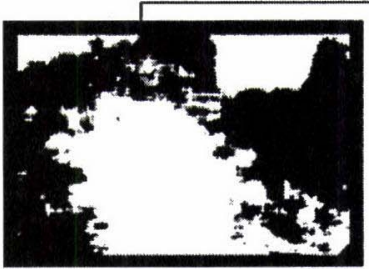

Without traversable plane estimation

a) Car on an inclining road

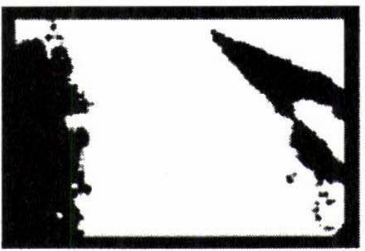

(b) Road with a side drain
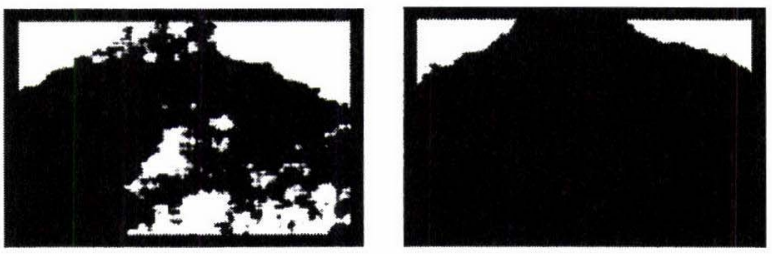

(c) Tilted path in the grass field
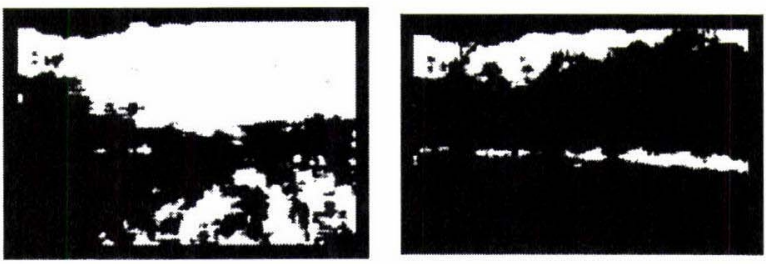

(d) Grand plane separated by a natural drain

Fig. 9 Experimental results for the actual field images 
法とそれを利用する段差に着目した走行可能路面の推定が適切 に動作することを示す. Fig. 9 に, 野外の様々な場面における 走行可能領域と障害物の検出結果を示している。これらのシー ンの路面は舗装されていないが, 車両が走行可能な場所である. ここでは，誌面の制約から限定した数例の処理例しか紹介でき ないが，処理装置は実時間で動作し，多くのシーンに対し実験 評価を行っている.Fig. 9 (a) は坂道の途中に対向車両が写る シーンである.Fig. 9 (b) は路肩に多少の起伏があり排水用の側 溝が写る場面である. Fig. 9 (c) は特殊車両等で走行可能な傾斜 した場所の草地の中の路面である. Fig. 9 (d) は平坦な自衛隊演 習場宿営地の中であるが, 中央部に自然にできた流水の溝が写 り，遠方は急激な段差があるシーンである.

Fig. 9 には, 傾斜平面ステレオで処理しても, 本論文の 4 章 「走行可能路面の推定と障害物の検出」で示した実際の走行可能 路面の位置を推定して, 障害物の検出をする処理を行わないと 正しく検出できない例を示している，前述のシーン（左）に対 し, モデル画像から理想的な路面（基準路面）と差を調べて単 純にしきい值処理して障害物検出した結果（中央），モデル画像 に本方法を適用して走行可能な路面を推定し障害物を検出した 結果（右）を示している，検出結果のうち，黒の領域が走行可 能領域で，白の領域が障害物として検出された領域である。処 理の関係上, 画像の外周 12 画素は処理対象外で黒領域として 表示している. 走行可能領域の推定を行わないと, 路面形状の 変化や車の動摇等による車両の傾きの影響で, これらのシーン では適切な障害物の検出がほとんどできていない.これに対し， 段差の検出により走行可能路面を推定する本方法では的確に走 行可能領域と障害物を検出できていることが分かる.

\section{6. 早い段階で高さの情報に変換することの有効性}

提案する傾斜平面ステレオを使用すれば, 傾斜平面ステレオ の特長である高さに関する情報を早い段階で直接求めることが できるため，これを用いて扱う領域やデー夕量を絞りこむこと により後処理での計算負荷を大きく低減できる，前章ではその 具体的例として, 野外シーンに対して提案する傾斜平面ステレ 才法とそれを利用する段差に着目した走行可能路面の推定が適 切に動作することを示した。この段差に着目した走行可能路面 の推定法も，それ自体, 他で提案されていない新しい方法であ る.しかし，この段差に着目した走行可能路面の推定法は, 提 案する傾斜平面ステレオ法を用いなければ行えないというわけ ではない. 例えば, 同じシーンに対して, 通常のステレオ処理 を利用してやったらどのようにな結果になるであろうか. 傾斜 平面ステレオ法で得られる障害物抽出の安定性の向上等を除け ば, 通常のステレオ処理から出発して処理しても, 傾斜平面ス テレオ法で直接高さの情報を得て処理しても，最終的に得られ る処理結果はほほ同じである。 なぜなら, 通常のステレオ視で も, その視差画像の各画素に対して適切な座標変換をしてやれ ば，画面全体の各画素が高さの情報を持つような形に変換でき るからである。しかし, 実際やってみると, この単純に見える 画面の全画素に対する座標変換（割り算を含む）が大変な量の 演算になる。

以下, 構築した実験システムを例に取り,この座標変換がど
の程度の処理負荷になるか, また最終的に達成できた処理速度 について述べる。一つ前の古い実験システムでは C40（TI 社 DSP）を複数使用し，多眼ステレオシステムを通常のステレオ 処理のモードで動作させ，座標変換により路面からの高さに変 換して処理を行っていた。この場合, 走行可能路面の推定と障 害物検出の処理に $800[\mathrm{~ms}]$ 程度の処理時間を要していた。これ を単純に傾斜平面ステレオに変更するだけで，162[ms]（約 5 倍）に高速化できている，よって，単純な座標変換が 638 [ms] も要していたことになる。次に，プロセッサをPentium IIIに 変えた新しいシステムでは, 傾斜平面ステレオを使用し, 使用 プロセッサの処理性能の向上や走行路面推定の方式の改善（本 論文の方法）等により, 走行可能路面の推定と障害物検出の処 理は $50[\mathrm{~ms}]$ 末満で処理を実行することができるようになって いる. 特別なプログラムの最適化等は行っておらず, 最適化を 行えば入力画像の速度（ビデオレート）に合わせ $33[\mathrm{~ms}]$ 以下 で処理も可能と考えられる。この処理性能は, 傾斜平面ステレ オ法で直接高さの情報を得て処理する方法, すなわち早い段階 で高さの情報に変換することにより達成できたものである.

\section{7. おわりに}

自律的または遠隔操縦で移動する車両等に必要となる, 段差 に着目した走行可能路面や障害物検出の方法とその有効性につ いて報告した，特に，ここでは車両が踏破できるかどうかの判 断基準である段差を効率的にとらえるためステレオ視に路面モ デルを導入した．本方法では，尺度として段差を計測するため 路面モデルを導入しているが, 写っているものが主として路面 であるというような特別な仮定をしていない. そのため, 提案 方法は, 従来方法と比較して, 野外不整地等の複雑な環境下で も，すなわち，どのような地形，どのような形の障害物が突然 現れても, 頑健に動作し高速処理が可能な処理方法となってい るのが最大の強みである. 本論文の方法で, 実際に野外で多様 な障害物を配置した中を車両を自走させ良好な結果を得ている.

\section{参 考 文 献}

[1] 徐剛, 辻三郎：3 次元ビジョン.p.100, 共立出版, 1998.

[2] S. Kimura, T. Shinbo, H. Yamaguchi, E. Kawamura and K. Nakano: "A Convolver-Based Real-Time Stereo Machine (SAZAN)," Conference on Computer Vision and Pattern Recognition 1999 (CVPR'99), pp.457-463, 1999.

[ 3 ] C. Thorpe, M.H. Herbert and T. Kanade: "Vision and Navigation for the Carnegie-Mellon Navlab," IEEE Trans. on Pattern Analysis and Machine Intelligence, vol.10, no.3, pp.362-373, 1988.

[4] 根岸慎治, 千葉昌孝, 小沢慎治: “高速道路における車両姿勢角推定に 基づく道路エッジの自動追跡”, 信学論, vol.J77-D-II, no.5, pp.931939, 1994.

[5] M. Bertozzi and A. Broggi: "GOLD : A Parallel Real-Time Stereo Vision System for Generic Obstacle and Lane Detection," IEEE Trans. on Image Processing, vol.7, no.1, pp.62-81, 1998.

[6] 小野口一則, 武田信之, 渡辺睦：“ステレオ画像の平面投影による移 動障害物位置検出”, 信学論, Vol.J81-D-II, no.8, pp.1895-1903, 1998.

[7] F. Li and M. Brady: "Modeling the Ground Plane Transformation for Real-Time Obstacle Detection," Computer Vision and Image Understanding, vol.71, no.1, pp.137-152, 1998. 
[8] 奥富正敏, 野口卓, 中野勝之：“ステレオ画像からの射影変換行列 の抽出による道路領域検出”, 日本ロボット学会誌, vol.18, no.8, pp.1105-1111, 2000.

[9] 小山剛弘, 松本吉央, 今井正和, 小笠原司：“ステレオ視覚と射影変 換を用いた移動ロボットの障害物検出と回避”, 第 18 回日本ロボッ 卜学会学術講演会予稿集, pp.997-998, 2000.

[10] 綱島宣浩, 宮岡大定, 中澤和夫, 中島真人: “ステレオ画像を用いた車 両前方障害物検出”, 電気学会論文誌, vol.118, no.5, pp.743-748, 1998.

[11] R. Mandelbaum, L. McDowell, L. Bogoni, B. Reich and M. Hansen: "Real-time stereo processing, obstacle detection, and terrain estimation from vehicle-mounted stereo camera," Proc. of the 4th IEEE Workshop on the Applications of Computer Vision, 1999.

[12] T. Williamson and C. Thorpe: "A Specialized Multi-baseline Stereo Technique for Obstacle Detection," Proc. of IEEE Conference on Computer Vision and Pattern Recognition (CVPR'98), 1998.

\section{付録 A. モデル值 $\boldsymbol{m}$ の平面の基準路面からの高さ}

三次元空間中の点 $(X, Y, Z)$ から平面 $A_{1} X+A_{2} Y+A_{3} Z+$ $A_{4}=0$ への距離は

$$
\pm \frac{A_{1} X+A_{2} Y+A_{3} Z+A_{4}}{\sqrt{A_{1}^{2}+A_{2}^{2}+A_{3}^{2}}}
$$

で与えられる。式 (6) からモデル值 $m$ の視差空間中の平面は

$$
d(x, y)=\frac{B}{H}(F \sin \theta-y \cos \theta)+\alpha m
$$

となる。よって, 画像座標 $(x, y)$ に写るモデル $m$ 点の対応す る三次元空間中の点の $\left(X_{0}, Y_{0}, Z_{0}\right)=\left(x Z_{0} / F, y Z_{0} / F, Z_{0}\right)$ は, ステレオ視における視差 $d$ と距離 $Z$ の式 (1) の関係から

$$
\left(X_{0}, Y_{0}, Z_{0}\right)=\frac{B H}{B(F \sin \theta-y \cos \theta)+\alpha m H}(x, y, F)
$$

となる.この点から, 式 (5) で表される水平な基準路面までの 距離を式（A.1）に対応させて求めると式（7）が得られる.

付録 B. モデル值 $m$ の平面の三次元空間中の勾配

式 (1) と $(x, y)^{t}=(F X / Z, F Y / Z)^{t}$ の射影変換の関係から, 視差空間中の平面 $d(x, y)=a x+b y+c$ は, カメラを中心と した $X Y Z$ 座標系では

$$
Z=-\frac{a F}{c} X-\frac{b F}{c} Y+\frac{B F}{c}
$$

の平面となる. また, モデル值 $m$ の視差空間中の平面は式 $(\mathrm{A} .2)$ であるから, そのカメラを中心とした $X Y Z$ 座標系の平面は

$$
Z=\frac{B F \cos \theta}{B F \sin \theta+\alpha m} Y+\frac{B F H}{B F \sin \theta+\alpha m}
$$

となる。また, カメラは下方に角度 $\theta$ だけ傾いており, 水平な 基準路面に合わせた座標系を $X^{\prime} Y^{\prime} Z^{\prime}$ として平面を表現し直 すと, $Z=Z^{\prime} \cos \theta-Y^{\prime} \sin \theta, Y=Z^{\prime} \sin \theta+Y^{\prime} \cos \theta$ である から

$$
Y^{\prime}=\frac{\alpha m H \cos \theta}{B F+\alpha m H \sin \theta} Z^{\prime}+\frac{B F H}{B F+\alpha m H \sin \theta}
$$

となる。よって, モデル值 $m$ の平面の勾配 $s(m)$ は式 (8) と なる。

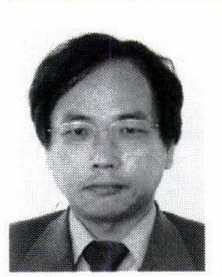

木村 茂 (Shigeru Kimura)

1955 年 11 月 4 日生. 1978 年名古屋工業大学電気 工学科卒業。1980 年名古屋大学修士課程修了. 同 年防衛庁技術研究本部入庁 (防衛庁技官). 1991 年 工学博士 (慶大). 1992 1994 年米カーネギーメロ ン大学客員研究員. 航空機搭載コンピュー夕, 動画 像処理システムなどの研究開発に従事. 現在, 防衛 庁技術研究本部第 2 研究所第 1 部情報システム室長. 電子情報通信 学会, 情報処理学会, IEEE 各会員. (日本ロボット学会正会員)

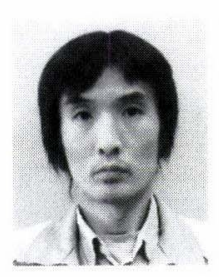

坂本卓也 (Takuya Sakamoto)

1964 年 7 月 29 日生. 1987 年千葉工業大学精密機 械工学科卒業. 1989 年千葉工業大学修士課程修了. 同年 (株) 小松製作所入社. 特機事業本部にてロ ボット, 特殊車両の研究開発に従事. ヒューマンイ ンタフェース学会会員。(日本ロボット学会正会員)

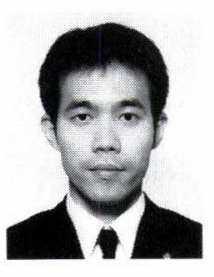

大橋洋一 (Yoichi Ohashi)

1976 年 3 月 1 日生. 1999 年中央大理工学部情報 工学科卒業. 2000 年防衛庁技術研究本部入庁 (防 衛庁技官)。モデリング\&シミュレーション，動画 像処理技術の研究開発に従事. 現在, 防衛庁技術研 究本部第 2 研究所第 1 部情報システム研究室所属. 電子情報通信学会, 人工知能学会各会員.

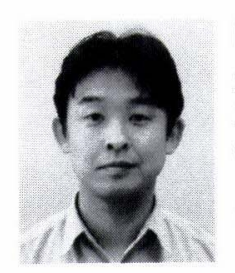

田野浩明 (Hiroaki Tano)

1969 年 5 月 9 日生. 1992 年北海道大学工学部精密 工学科卒業. 1994 年北海道大学修士課程修了. 同 年 (株) 小松製作所入社. 特機事業本部にてロボッ 卜, 特殊車两の研究開発に従事. 計測自動制御学会 会員.

(日本ロボット学会正会員)

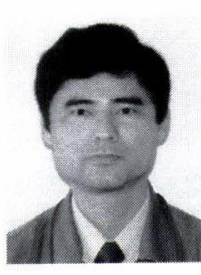

城間晴輝 (Haruki Shiroma)

1955 年 3 月 7 日生. 1979 年琉球大学理工学部電 気工学科卒業. 同年沖縄開発庁入庁 (総理府技官). 1982 年防衛庁技術研究本部入庁 (防衛庁技官). 戦 闘車再の操縦性. 安定性の研究開発に従事. 現在, 防衛庁技術研究本部第 4 研究所総合試験室第 1 試 験班長. 電子情報通信学会会員. 